\title{
Influence of the anode material on the degradation of naproxen by Fenton-based electrochemical processes
}

Gabriela Coria $^{1}$, Ignasi Sirés ${ }^{2, *}$, Enric Brillas ${ }^{2}$, José L. Nava ${ }^{1, * *}$

${ }^{1}$ Departamento de Ingeniería Geomática e Hidráulica, Universidad de Guanajuato, Av. Juárez 77, Zona Centro, C.P 36000 Guanajuato, Guanajuato, Mexico

${ }^{2}$ Laboratori d'Electroquímica dels Materials i del Medi Ambient, Departament de Química Física, Facultat de Química, Universitat de Barcelona, Martí i Franquès 1-11, 08028 Barcelona, Spain

Paper submitted to be published in Chemical Engineering Journal

*Corresponding author: $\quad$ Tel.: +34 934039240; fax: +34 934021231.

E-mail address: i.sires@ub.edu (I. Sirés)

**Corresponding author: Tel.: + 01 (473) 1020 100, 7320006 ext. 2289; fax: + 2209.

E-mail address: jlnm@ugto.mx (J.L. Nava) 


\section{Abstract}

This study focuses on the role of the anode material for the electrochemical degradation of the top-selling anti-inflammatory drug naproxen (NPX). Aqueous solutions containing $40 \mathrm{mg} \mathrm{\textrm {L } ^ { - 1 }}$ NPX sodium in $0.050 \mathrm{M} \mathrm{NaClO}_{4}$ at pH 3.0 were comparatively treated by electrochemical advanced oxidation processes (EAOPs) like electro-oxidation with electrogenerated $\mathrm{H}_{2} \mathrm{O}_{2}$ $\left(\mathrm{EO}-\mathrm{H}_{2} \mathrm{O}_{2}\right)$, electro-Fenton (EF) and UVA photoelectro-Fenton (PEF). The experiments were performed in a $2.5 \mathrm{~L}$ flow plant equipped with an annular glass photoreactor coupled to a cell with a Pt, $\mathrm{IrO}_{2}$-based (DSA-O $\left.{ }_{2}\right), \mathrm{RuO}_{2}$-based $\left(\mathrm{DSA}^{\left.-\mathrm{Cl}_{2}\right)}\right.$ or boron-doped diamond (BDD) anode and an air-diffusion cathode to electrogenerate $\mathrm{H}_{2} \mathrm{O}_{2}$. In EF and PEF, $0.50 \mathrm{mM} \mathrm{Fe} \mathrm{F}^{2+}$ was added as catalyst. At $50 \mathrm{~mA} \mathrm{~cm}^{-2}$, the oxidation power of EAOPs rose in the order: EO$\mathrm{H}_{2} \mathrm{O}_{2}<\mathrm{EF}<\mathrm{PEF}$, regardless of the anode used. The $\mathrm{IrO}_{2}$-based anode led to greater mineralization in EO- $\mathrm{H}_{2} \mathrm{O}_{2}$ and EF. In contrast, the BDD anode allowed an almost total mineralization in PEF, being superior to $85 \%$ attained with the other three materials. DSA, a significantly cheap anode compared to Pt and BDD, can then be a suitable candidate for treating NPX solutions by EAOPs. For each process, the mineralization current efficiency and specific energy consumption were determined. The NPX concentration decay always followed a pseudo-first-order kinetics and, in PEF, it was enhanced in the sequence: $\mathrm{RuO}_{2}$ based $<\mathrm{Pt}<\mathrm{BDD}<\mathrm{IrO}_{2}$-based. GC-MS analysis of treated solutions allowed detecting six aromatic products, whereas maleic and oxalic acids were identified by ion-exclusion HPLC. A reaction sequence for the degradation of NPX by EAOPs is finally proposed.

Keywords: BDD; DSA; Electrochemical oxidation; Electro-Fenton; Naproxen; PhotoelectroFenton 


\section{Introduction}

The unpredictable consequences arising from the presence of pharmaceuticals in the aquatic environment have stimulated an intense investigation in all areas within this field, including the development of technologies to enhance their removal [1]. These pollutants are continuously introduced into the ecosystems, which affects the quality of drinking water supplies and constitutes a potential environmental impact on ecosystems and human health [2]. Their occurrence in water comes pre-eminently from improper disposal as well as through human and animal excretion. They are difficult to remove in wastewater treatment facilities (WWTFs) and, consequently, they become persistent pollutants in water [3-5].

Non-steroidal anti-inflammatory drugs (NSAIDs) are commonly employed for the treatment of fever and pain in adults. They are released to the aquatic as either pristine compounds or metabolites $[4,6]$. Naproxen (NPX, usually commercialized as sodium salt of (+)-(S)-2-(6-methoxynaphthalen-2-yl)propanoate, $\mathrm{NaC}_{14} \mathrm{H}_{13} \mathrm{O}_{3}, M=230.26 \mathrm{~g} \mathrm{~mol}^{-1}$ ) is a widely used NSAID in human and animal medicine. It is frequently detected in WWTFs and surface water due to its large persistence, whereas its photodegradation by-products are even more toxic than the parent drug [3-6].

The effective destruction of toxic and biorefractory pollutants is an important, urgent issue in modern societies. Since low removal percentages are reported for pharmaceuticals in conventional WWTFs, more powerful technologies are needed [3]. It is not surprising, therefore, that the electrochemical advanced oxidation processes (EAOPs) like electrooxidation (EO), electro-Fenton (EF) and photoelectro-Fenton (PEF) have received increasing attention in recent years [7,8]. They are environmentally friendly technologies that have shown good prospective for the abatement of pharmaceuticals in wastewater. EAOPs are based on the in situ production of hydroxyl radicals $\left({ }^{\circ} \mathrm{OH}\right)$, which are potent oxidants capable of degrading persistent organic pollutants until their mineralization to $\mathrm{CO}_{2}[3,4,7]$. 
The simplest and most widespread EAOP is EO, where organics are oxidized by physisorbed hydroxyl radicals $\mathrm{M}\left({ }^{\bullet} \mathrm{OH}\right)$ generated at high current from water discharge via reaction (1) at the surface of the anode $\mathrm{M}$, including Pt [4,9], dimensionally stable anodes (DSA) based on $\mathrm{RuO}_{2}$ or $\mathrm{IrO}_{2}$ [10-14], $\mathrm{SnO}_{2}, \mathrm{PbO}_{2}$ and boron-doped diamond (BDD) thinfilm electrodes $[9,15]$. Among them, BDD is the preferred anode in EO because the weak interaction between ${ }^{\bullet} \mathrm{OH}$ and its surface, along with its larger $\mathrm{O}_{2}$-overpotential, yields greater amounts of $\mathrm{M}\left({ }^{\bullet} \mathrm{OH}\right)$ with ability to mineralize persistent organic pollutants in water.

$\mathrm{M}+\mathrm{H}_{2} \mathrm{O} \rightarrow \mathrm{M}\left({ }^{\circ} \mathrm{OH}\right)+\mathrm{H}^{+}+\mathrm{e}^{-}$

On the other hand, one of the main drawbacks of the chemical Fenton's reagent for wastewater treatment is the high cost associated with $\mathrm{H}_{2} \mathrm{O}_{2}$ consumption $[15,16]$. This can be overcome by using EAOPs where $\mathrm{H}_{2} \mathrm{O}_{2}$ is electrogenerated at the cathode from the twoelectron reduction of injected $\mathrm{O}_{2}$ from reaction (2), being carbon-felt [17-19] and carbonpolytetrafluoroethylene (PTFE) gas $\left(\mathrm{O}_{2}\right.$ or air) diffusion electrodes very effective $[8,19,20]$.

$\mathrm{O}_{2(\mathrm{~g})}+2 \mathrm{H}^{+}+2 \mathrm{e}^{-} \rightarrow \mathrm{H}_{2} \mathrm{O}_{2}$

In an undivided cell, the EO process with electrogenerated $\mathrm{H}_{2} \mathrm{O}_{2}\left(\mathrm{EO}-\mathrm{H}_{2} \mathrm{O}_{2}\right)$ can then be applied, with the destruction of organics mainly resulting from the attack of $\mathrm{M}\left({ }^{\bullet} \mathrm{OH}\right)$, as well as from weaker reactive oxygen species (ROS) like $\mathrm{H}_{2} \mathrm{O}_{2}$ and hydroperoxyl radical $\mathrm{M}_{\left(\mathrm{HO}_{2}\right.}{ }^{\bullet}$ ), formed as an intermediate of $\mathrm{O}_{2}$ evolution via reaction (3) $[8,20]$ :

$\mathrm{M}+\mathrm{H}_{2} \mathrm{O}_{2} \rightarrow \mathrm{M}\left(\mathrm{HO}_{2}^{\circ}\right)+\mathrm{H}^{+}+\mathrm{e}^{-}$

In EF, the organic pollutants may undergo the additional attack of ${ }^{\bullet} \mathrm{OH}$ originated in the bulk by Fenton's reaction (4) between generated $\mathrm{H}_{2} \mathrm{O}_{2}$ and small quantities of added $\mathrm{Fe}^{2+}$ at optimum $\mathrm{pH} \sim 3$. This reaction is catalytic and can be propagated from $\mathrm{Fe}^{2+}$ regeneration by $\mathrm{Fe}^{3+}$ reduction at the cathode $[3,4,15,16]$. 
$\mathrm{H}_{2} \mathrm{O}_{2}+\mathrm{Fe}^{2+} \rightarrow \mathrm{Fe}^{3+}+{ }^{\circ} \mathrm{OH}+\mathrm{OH}^{-}$

Hydroxyl radicals can be consumed by waste reactions that reduce the oxidation power and efficiency of EF. In PEF, the solution is additionally irradiated with artificial UVA light within the range $320-400 \mathrm{~nm}[4,8,15]$. This radiation favors the degradation of organic pollutants promoting: (i) a quicker $\mathrm{Fe}^{2+}$ regeneration and $\bullet \mathrm{OH}$ production from $\mathrm{Fe}(\mathrm{OH})^{2+}$ photoreduction by reaction (5), and (ii) the photoreduction of final Fe(III)-carboxylate complexes from reaction (6) $[8,20,21]$.

$\mathrm{Fe}(\mathrm{OH})^{2+}+h v \rightarrow \mathrm{Fe}^{2+}+{ }^{\circ} \mathrm{OH}$

$\mathrm{Fe}(\mathrm{OOCR})^{2+}+h v \rightarrow \mathrm{Fe}^{2+}+\mathrm{CO}_{2}+\mathrm{R}^{\cdot}$

Physicochemical treatments such as adsorption on activated carbon [22,23] and photolysis $[24,25]$ have been explored to remove NPX from aqueous solutions. A more effective destruction has been described by several AOPs like ozonation [26], photo-Fenton [27], $\mathrm{TiO}_{2}$ photocatalysis [28] and sono-assisted processes [29,30]. Interestingly, EO with Pt and BDD anodes has been the only EAOP tested so far [6,31,32].

The generation of oxidants in the EAOPs depends of the electrode materials and the operation parameters. In particular, little is known about the role of $\mathrm{RuO}_{2}$ - and $\mathrm{IrO}_{2}$-based anodes in EF and PEF treatments of pharmaceuticals [33-36]. This study is necessary since DSA is much less expensive than Pt and BDD, which are the most studied anodes in EAOPs, and could become highly appealing for the application of EF and PEF at industrial scale.

This paper presents a comparative study on the degradation of acidic aqueous solutions of $\mathrm{NPX}$ in $0.050 \mathrm{M} \mathrm{NaClO}_{4}$ at $\mathrm{pH} 3.0$ by EO- $\mathrm{H}_{2} \mathrm{O}_{2}$, EF and PEF. The assays were performed in a $2.5 \mathrm{~L}$ flow plant containing an electrochemical cell equipped with a Pt, $\mathrm{RuO}_{2}$-based, $\mathrm{IrO}_{2}$ based or BDD anode and an air-diffusion cathode in order to clarify the influence of the different anode materials on each EAOP. A perchlorate salt was chosen as background 
electrolyte since it is inert and does not interfere in the reactivity of produced hydroxyl radicals [8,37]. The effect of the applied current density $(j)$ on the NPX decay and mineralization rate was examined. The kinetic decay of the pharmaceutical and the evolution of final carboxylic acids were determined by high-performance liquid chromatography (HPLC), whereas primary aromatic intermediates were identified by gas chromatography coupled to mass spectrometry (GC-MS). Based on the identified products, a reaction sequence for the initial degradation of NPX by EAOPs is proposed.

\section{Materials and methods}

\subsection{Chemicals}

Naproxen sodium with $>98 \%$ purity was supplied by Sigma-Aldrich. Perchloric acid (70\%) and sodium hydroxide were of analytical grade supplied by Merck and Panreac, respectively. Analytical grade iron (II) sulfate heptahydrate used as catalyst in EF and PEF was purchased from Fluka. All the solutions were prepared with deionized water. Carboxylic acids, organic solvents and other chemicals were of HPLC or analytical grade supplied by Sigma-Aldrich, Merck and Panreac.

\subsection{Flow plant}

A sketch of the flow plant designed by us to operate in batch mode and used in this work is shown in Fig. SM-1 of Supplementary Material. Each trial involved the recirculation of 2.5 L of a NPX solution, introduced into a reservoir, through the plant by a centrifugal pump, keeping the flow rate at $180 \mathrm{~L} \mathrm{~h}^{-1}$ with a flowmeter and the solution temperature at $35{ }^{\circ} \mathrm{C}$ with two heat exchangers connected to a water bath. The electrochemical reactor was an undivided filter-press cell equipped with a $20 \mathrm{~cm}^{2}$ anode and a $20 \mathrm{~cm}^{2}$ carbon-PTFE air-diffusion cathode from E-TEK, separated $1.2 \mathrm{~cm}$. Four anodes were utilized: (i) a Pt sheet (99.99\% purity) from SEMPSA, (ii) a DSA-O ${ }_{2}$ plate ( $\mathrm{IrO}_{2}$-based anode) from NMT Electrodes, (iii) a 
DSA-Cl 2 plate $\left(\mathrm{RuO}_{2}\right.$-based anode) from NMT Electrodes, and (iv) a BDD thin-film electrode, deposited onto $p$-Si, from NeoCoat. A PVC gas chamber fed with atmospheric air at an overpressure of $8.6 \mathrm{kPa}$ regulated with a back-pressure gauge was in contact with the cathode for continuous $\mathrm{H}_{2} \mathrm{O}_{2}$ production. The assays were performed at constant $j$ controlled by a Grelco GVD310 (0-10 A) power supply, directly providing the potential difference between electrodes. All the experiments were carried out with an annular Schott-Duran glass photoreactor of $210 \mathrm{~mm}$ height, $110 \mathrm{~mm}$ external diameter and $10 \mathrm{~mm}$ thickness, whose capacity was $640 \mathrm{~mL}$, connected to the outlet of the electrochemical reactor to keep the same flow rate in all EAOPs. For PEF trials, a 160-W Philips black light blue lamp of $\lambda_{\max }=360$ nm was placed inside the annular photoreactor to irradiate the solution.

All the 2.5 L solutions contained $0.050 \mathrm{M} \mathrm{NaClO}_{4}$ as background electrolyte. They were prepared by neutralizing the required amount of $\mathrm{HClO}_{4}$ with $\mathrm{NaOH}$. Afterwards, the solution $\mathrm{pH}$ was adjusted to 3.0 with $\mathrm{HClO}_{4}$. The specific conductivity of solutions was $4.1 \mathrm{mS} \mathrm{cm}{ }^{-1}$. EO- $\mathrm{H}_{2} \mathrm{O}_{2}$, EF and PEF treatments of the above solutions with around $40 \mathrm{mg} \mathrm{L}^{-1} \mathrm{NPX}$ sodium (corresponding to near saturation at acidic $\mathrm{pH}$ ) were performed with $\mathrm{Pt}$ /air-diffusion, $\mathrm{IrO}_{2}$ based/air-diffusion, $\mathrm{RuO}_{2}$-based/air-diffusion and $\mathrm{BDD} /$ air-diffusion cells at $50 \mathrm{~mA} \mathrm{~cm}{ }^{-2}$. This high NPX sodium concentration was chosen to compare the degradation rate of the processes and to better identify the oxidation products generated. It was stable in the perchloric medium used. The effect of $j$ between 10 and $50 \mathrm{~mA} \mathrm{~cm}^{-2}$ on the oxidation power of the PEF process was examined. In EF and PEF, $0.50 \mathrm{mM} \mathrm{Fe}{ }^{2+}$ was used as optimum catalyst content [38-40].

\subsection{Apparatus and analytical methods}

The solution $\mathrm{pH}$ was determined on a Crison 2000 pH-meter. The accumulated $\mathrm{H}_{2} \mathrm{O}_{2}$ concentration was obtained from the light absorption of the titanic-hydrogen peroxide colored complex at $\lambda=408 \mathrm{~nm}[41]$. 
The mineralization of the NPX sodium solutions was monitored from their total organic carbon (TOC) abatement, measured on a Shimadzu VCSN TOC analyzer. To do this, samples withdrawn from treated solutions at given times were microfiltered with $0.45 \mu \mathrm{m}$ PTFE filters from Whatman, followed by immediate injection of $50 \mu \mathrm{L}$ aliquots into the analyzer, thus obtaining reproducible TOC values with $\pm 1 \%$ accuracy.

Since NPX is expected to be mineralized to carbon dioxide as follows:

$\mathrm{C}_{14} \mathrm{H}_{13} \mathrm{O}_{3}^{-}+25 \mathrm{H}_{2} \mathrm{O} \rightarrow 14 \mathrm{CO}_{2}+63 \mathrm{H}^{+}+64 \mathrm{e}^{-}$

the above TOC data were used to estimate the mineralization current efficiency (MCE) for each treated solution at a given time $t$ (in h) from Eq. (8) [38]:

$\operatorname{MCE}(\%)=\frac{n F V_{S} \Delta(\mathrm{TOC})_{\exp }}{4.32 \times 10^{7} \text { I I }} \times 100$

where $n$ is the number of electrons consumed per drug molecule $(=64), F$ is the Faraday constant (=96,487 $\left.\mathrm{C} \mathrm{mol}^{-1}\right), V_{\mathrm{s}}$ is the solution volume (in L), $\Delta(\mathrm{TOC}$ )exp is the experimental TOC abatement (in mg of $\mathrm{C} \mathrm{L}^{-1}$ ), $4.32 \times 10^{7}$ is a conversion factor to homogenize units (= $\left.3,600 \mathrm{~s} \mathrm{~h}^{-1} \mathrm{x} 12,000 \mathrm{mg} \mathrm{C} \mathrm{mol}^{-1}\right), \mathrm{m}$ is the number of carbon atoms of NPX (=14) and $I$ is the applied current (in A). The energy consumption per unit TOC mass (EC $\mathrm{TOC}_{\text {) }}$ at time $t$ (in $\mathrm{h}$ ) was determined as follows [38]:

$\mathrm{EC}_{\mathrm{TOC}}\left(\mathrm{kWh}(\mathrm{g} \mathrm{TOC})^{-1}\right)=\frac{E_{\text {cell }} I t}{V_{s} \Delta(\mathrm{TOC})_{\exp }}$

where $E_{\text {cell }}$ is the average potential difference between the anode and cathode, with a value of 15.0 V for EAOPs with Pt, $\mathrm{RuO}_{2}$-based and $\mathrm{IrO}_{2}$-based anodes at $50 \mathrm{~mA} \mathrm{~cm}{ }^{-2}$, and 7.1, 11.0 and 19.2 V using BDD at 10, 25 and $50 \mathrm{~mA} \mathrm{~cm}^{-2}$, respectively.

The kinetic decay of NPX was determined by analyzing the degraded solutions by reversed-phase HPLC through a Waters 600 LC fitted with a BDS Hypersil C18 $6 \mu \mathrm{m}, 250$ $\mathrm{mm} \times 4.6 \mathrm{~mm}$, column at $35{ }^{\circ} \mathrm{C}$ and coupled to a Waters 996 photodiode array detector set at $\lambda=230 \mathrm{~nm}$. In the EF and PEF experiments, the aqueous samples were diluted with the same 
volume of acetonitrile to stop the degradation process. These measurements were made by injecting $20 \mu \mathrm{L}$ aliquots into the LC after microfiltration with $0.45 \mu \mathrm{m}$ PTFE filters from Whatman using a 60:40 (v/v) acetonitrile/water mixture at $0.6 \mathrm{~mL} \mathrm{~min}^{-1}$ as mobile phase. The chromatograms displayed a well-defined peak related to NPX at retention time $\left(t_{\mathrm{r}}\right)$ of $8.2 \mathrm{~min}$. Final carboxylic acids were identified by ion-exclusion HPLC using the above LC fitted with a Bio-Rad Aminex HPX 87H, $300 \mathrm{~mm} \times 7.8 \mathrm{~mm}$, column at $35{ }^{\circ} \mathrm{C}$ and the photodiode detector selected at $\lambda=210 \mathrm{~nm}$. Aliquots of $20 \mu \mathrm{L}$ were also injected into the LC and the mobile phase was a $4 \mathrm{mM} \mathrm{H} \mathrm{H}_{2}$ solution eluted at $0.6 \mathrm{~mL} \mathrm{~min}^{-1}$. The chromatograms showed well-defined peaks at 6.9 and 9.0 min related to oxalic and maleic acids, respectively.

Several solutions with $40 \mathrm{mg} \mathrm{L} \mathrm{L}^{-1} \mathrm{NPX}$ sodium in $0.050 \mathrm{M} \mathrm{NaClO}_{4}$ at $\mathrm{pH} 3.0$ were electrolyzed for short times by EO- $\mathrm{H}_{2} \mathrm{O}_{2}$ and EF with a BDD/air-diffusion cell at $50 \mathrm{~mA} \mathrm{~cm}{ }^{-2}$ to identify the aromatic products formed. The organic compounds contained in $200 \mathrm{~mL}$ of each treated solution were extracted with $\mathrm{CH}_{2} \mathrm{Cl}_{2}(3 \times 25 \mathrm{~mL})$ and the resulting fraction was dried over anhydrous $\mathrm{Na}_{2} \mathrm{SO}_{4}$, filtered and concentrated up to ca. $1 \mathrm{~mL}$ to be analyzed by GCMS, using a NIST05 MS library to identify the mass spectra. This analysis was made with an Agilent Technologies system composed of a 7890A gas chromatograph and a 5975C mass spectrometer operating in EI mode at $70 \mathrm{eV}$. Non-polar Agilent J\&W HP-5ms or polar HP INNOWax columns, both of $0.25 \mu \mathrm{m}, 30 \mathrm{~m} \times 0.25 \mathrm{~mm}$, were used. The temperature ramp was $36{ }^{\circ} \mathrm{C}$ for $1 \mathrm{~min}, 5{ }^{\circ} \mathrm{C} \mathrm{min}^{-1}$ up to $300{ }^{\circ} \mathrm{C}$ for the non-polar or $250{ }^{\circ} \mathrm{C}$ for the polar column, respectively, and hold time $10 \mathrm{~min}$. The temperature of the inlet, source and transfer line was 250, 230 and $280{ }^{\circ} \mathrm{C}$ or 250,230 and $250^{\circ} \mathrm{C}$ for the non-polar and polar column, respectively.

\section{Results and discussion}

\subsection{Accumulation of $\mathrm{H}_{2} \mathrm{O}_{2}$ in the electrolytic systems}


To characterize the ability of the electrolytic systems to accumulate $\mathrm{H}_{2} \mathrm{O}_{2}$ from reaction (2), solutions containing the background electrolyte $(0.050 \mathrm{M} \mathrm{NaClO} 4)$ at $\mathrm{pH} 3.0$ were electrolyzed in the absence of $\mathrm{Fe}^{2+}$ using Pt or BDD as the anode and an air-diffusion cathode at $j=50 \mathrm{~mA} \mathrm{~cm}{ }^{-2}$, i.e., under $\mathrm{EO}-\mathrm{H}_{2} \mathrm{O}_{2}$ conditions. Fig. 1a highlights a quick rise in $\mathrm{H}_{2} \mathrm{O}_{2}$ concentration using Pt up to reach $28.6 \mathrm{mM}$ after $360 \mathrm{~min}$ of electrolysis. In contrast, the content of this species increased much more slowly using BDD, only attaining $10 \mathrm{mM}$ at the same time. This suggests that the BDD anode promotes more largely than Pt the oxidation of $\mathrm{H}_{2} \mathrm{O}_{2}$ by reaction (3), prior to further $\mathrm{O}_{2}$ evolution from the $\mathrm{HO}_{2}{ }^{\bullet}$ formed $[41,42]$ :

$\mathrm{M}\left(\mathrm{HO}_{2}^{\circ}\right) \rightarrow \mathrm{M}+\mathrm{O}_{2}+\mathrm{H}^{+}+\mathrm{e}^{-}$

A further study was made by adding $0.50 \mathrm{mM} \mathrm{Fe}{ }^{2+}$ to the $2.5 \mathrm{~L}$ of $0.050 \mathrm{M} \mathrm{NaClO}_{4}$ solution at $\mathrm{pH} 3.0$ to be electrolyzed at $j=50 \mathrm{~mA} \mathrm{~cm}^{-2}$ for 360 min under EF conditions using the four anodes. A remarkable influence of the anode on $\mathrm{H}_{2} \mathrm{O}_{2}$ accumulation can be observed in Fig. 1b. At 60 min of electrolysis, for example, the $\mathrm{H}_{2} \mathrm{O}_{2}$ concentration was $0.53,1.31,2.06$ and $2.92 \mathrm{mM}$ for $\mathrm{RuO}_{2}$-based, $\mathrm{IrO}_{2}$-based, $\mathrm{BDD}$ and Pt, respectively. This relative trend was maintained up to 240 min, whereupon a slightly higher $\mathrm{H}_{2} \mathrm{O}_{2}$ content was accumulated in BDD compared to Pt. For these four anodes, 3.90, 4.97, 5.42 and $5.09 \mathrm{mM} \mathrm{H}_{2} \mathrm{O}_{2}$ were finally obtained. Note that both DSA yielded a linear trend for $\mathrm{H}_{2} \mathrm{O}_{2}$ accumulation, being the slope steeper for the $\mathrm{IrO}_{2}$-based one, which finally yielded a similar amount to that obtained with Pt. Comparison of these results with those of Fig. 1a for EO- $\mathrm{H}_{2} \mathrm{O}_{2}$ with Pt and BDD allows concluding that the presence of $\mathrm{Fe}^{2+}$ causes a rapid decay of $\mathrm{H}_{2} \mathrm{O}_{2}$ concentration via Fenton's reaction (4), thereby producing large amounts of ${ }^{\bullet} \mathrm{OH}$ in the bulk that make the EF process very effective. The larger $\mathrm{H}_{2} \mathrm{O}_{2}$ accumulation in the order: $\mathrm{RuO}_{2}$-based $<\mathrm{IrO}_{2}$-based $\sim \mathrm{Pt}<$ BDD can then be related to the parallel oxidation of $\mathrm{H}_{2} \mathrm{O}_{2}$ at the anode by reaction (3), as well as the ability of $\mathrm{Fe}^{2+}$ regeneration at the cathode, which is also influenced by its anodic oxidation to $\mathrm{Fe}^{3+}$ at the anode [43]. Consequently, all the anodes tested showed a good ability 
to accumulate $\mathrm{H}_{2} \mathrm{O}_{2}$ in the medium in EF, thus ensuring a significant generation of $\mathrm{M}\left({ }^{\bullet} \mathrm{OH}\right)$ and ${ }^{\bullet} \mathrm{OH}$ to oxidize organic compounds.

The ability of the Pt/air-diffusion and BDD/air-diffusion cells to generate and accumulate $\mathrm{H}_{2} \mathrm{O}_{2}$ in $2.5 \mathrm{~L}$ of $0.050 \mathrm{M} \mathrm{NaClO}_{4}$ with $0.50 \mathrm{mM} \mathrm{Fe}^{2+}$ at $\mathrm{pH} 3.0$ was finally examined under PEF conditions, i.e., by irradiating the solution circulating by the annular glass photoreactor with a 160-W UVA lamp. The results obtained for these trials at $j=50 \mathrm{~mA} \mathrm{~cm}{ }^{-2}$ are also presented in Fig. 1b. As can be seen, a drastic reduction of $\mathrm{H}_{2} \mathrm{O}_{2}$ content compared to that of EF process was found in both cases, attaining a similar value close to $1.9 \mathrm{mM}$ at the end of the electrolysis. This result can be related to the quicker $\mathrm{Fe}^{2+}$ regeneration from the photolytic reaction (5) that accelerates Fenton's reaction (4) with the consequent consumption of $\mathrm{H}_{2} \mathrm{O}_{2}$ and larger production of $\bullet \mathrm{OH}$. Note that Fig. $1 \mathrm{~b}$ evidences that $\mathrm{H}_{2} \mathrm{O}_{2}$ achieved a steady state after 240 min of PEF, suggesting that it was attained just when its production rate at the cathode by reaction (2) became equal to its destruction rate via reactions (3)-(5). These findings indicate again that each electrolytic system is able to generate and accumulate $\mathrm{H}_{2} \mathrm{O}_{2}$ in order to produce high amounts of hydroxyl radicals, which are expected to be formed to larger extent in PEF than in EF.

\subsection{Comparative degradation with $\mathrm{Pt}$, $\mathrm{IrO}_{2}$-based, $\mathrm{RuO}_{2}$-based and $\mathrm{BDD}$ anodes by EAOPs}

Solutions of $2.5 \mathrm{~L}$ with $40 \mathrm{mg} \mathrm{L}^{-1} \mathrm{NPX}$ sodium in $0.050 \mathrm{M} \mathrm{NaClO}_{4}$ at $\mathrm{pH} 3.0$ were degraded by the different EAOPs in the flow plant with Pt/air-diffusion, $\mathrm{IrO}_{2}$-based/airdiffusion, $\mathrm{RuO}_{2}$-based/air-diffusion or BDD/air-diffusion cells at $j=50 \mathrm{~mA} \mathrm{~cm}{ }^{-2}$ for $360 \mathrm{~min}$. In EF and PEF, $0.50 \mathrm{mM} \mathrm{Fe}{ }^{2+}$ was added as catalyst of Fenton's reaction (4). All treated solutions became slightly more acid during electrolysis, attaining final values of 2.7-2.8, thus suggesting the formation of acidic products like short aliphatic carboxylic acids $[18,21,38]$. Treated solutions were always colorless in the $\mathrm{EO}-\mathrm{H}_{2} \mathrm{O}_{2}$ treatments, whereas they acquired a pale yellow color after a few minutes of EF and PEF degradations, probably due to the 
formation of complexes of some products with Fe(III). The solutions became again colorless after 60-90 min of electrolysis, once such complexes became oxidized [28].

Fig. 2a-d depict the normalized TOC-time plots obtained for these assays. A quick look to these figures allows concluding that the oxidation ability of EAOPs grew in the sequence EO- $\mathrm{H}_{2} \mathrm{O}_{2}<\mathrm{EF}<\mathrm{PEF}$, regardless of the anode used. The former process was less potent because of the slower destruction of NPX and its intermediates by the corresponding oxidants $\mathrm{M}\left({ }^{\bullet} \mathrm{OH}\right)$ originated at each anode from reaction $(1)[9,44]$. The Pt anode led to the poorest mineralization, with a maximum TOC decay of $6.5 \%$ at 360 min (see Fig. 2a), whereas at this time TOC was reduced by about 23-25\% using the $\mathrm{RuO}_{2}$-based (see Fig. 2c) and BDD (see Fig. 2d) anodes and up to $36 \%$ with the $\mathrm{IrO}_{2}$-based one (see Fig. 2b). This is a rather surprising result since it is usually considered that BDD is the most powerful anode for EO $[9,15]$. However, for this pollutant, the $\mathrm{IrO}_{2}$-based anode possessed superior oxidation ability, probably due to the greater adsorption of organics onto its surface, which enhances their reaction with ${ }^{\bullet} \mathrm{OH}$ physisorbed on the anode. The poor mineralization of NPX solution by EO with a BDD anode has also been reported by González et al. [31], who found a maximum TOC removal of 38\% operating at alkaline $\mathrm{pH}$ of 10.7 and at a very great $j$ of $194 \mathrm{~mA} \mathrm{~cm}{ }^{-2}$.

Fig. 2a-d highlight a quite similar mineralization for the EF process with $\mathrm{IrO}_{2}$-based, $\mathrm{RuO}_{2}$-based and BDD anodes, attaining final TOC abatements of $46 \%-49 \%$, higher than $40 \%$ found for Pt. The remarkable enhancement compared to EO- $\mathrm{H}_{2} \mathrm{O}_{2}$ corroborates the parallel oxidation in the bulk by ${ }^{\bullet} \mathrm{OH}$ formed from Fenton’s reaction (4) along with that promoted by physisorbed $\mathrm{M}\left({ }^{\bullet} \mathrm{OH}\right)$. Note that different intermediates were produced in both treatments owing to the formation of iron complexes in EF, as pointed out above. The degradation resulting from the attack of $\mathrm{M}\left({ }^{\bullet} \mathrm{OH}\right)$ and ${ }^{\bullet} \mathrm{OH}$ was very similar in $\mathrm{EF}$ with $\mathrm{IrO}_{2}$-based, $\mathrm{RuO}_{2}$ based and BDD anodes, whereas the lower mineralization achieved using Pt suggests a much lower oxidation ability of $\operatorname{Pt}\left({ }^{\bullet} \mathrm{OH}\right)$, in agreement with the scarce TOC removal found with this 
anode in EO- $\mathrm{H}_{2} \mathrm{O}_{2}$ (see Fig. 2a). It is also noticeable that in all the EF processes the quicker mineralization of the drug solution was attained up to 180-240 min of electrolysis, whereas at longer times TOC abatement was progressively decelerated. This is indicative of the formation of very recalcitrant products that are not removed by $\mathrm{M}\left({ }^{\bullet} \mathrm{OH}\right)$ and ${ }^{\bullet} \mathrm{OH}$ in each cell. In contrast, most of products were photosensitive under UVA light irradiation, rapidly disappearing in PEF. As can be seen in Fig. 2a-d, TOC was quickly abated for 120 min in all cases and, at that time, the mineralization achieved was $80 \%$ for $\mathrm{Pt}, 78 \%$ for $\mathrm{IrO}_{2}$-based, $76 \%$ for $\mathrm{RuO}_{2}$-based and $83 \%$ for $\mathrm{BDD}$. At longer time, the presence of highly recalcitrant products caused a strong deceleration of the degradation and only the BDD anode led to an almost total mineralization of $91 \%$, whereas a value of ca. $85 \%$ was obtained with the other anodes. From these findings, one can conclude that PEF in the flow plant with the BDD/airdiffusion cell was the most powerful process for the treatment of the $40 \mathrm{mg} \mathrm{L}^{-1} \mathrm{NPX}$ sodium solution at $\mathrm{pH} 3.0$, as a result of the greater oxidation of organics upon synergistic action of $\operatorname{BDD}\left(\bullet^{\circ} \mathrm{OH}\right), \bullet \mathrm{OH}$ and UVA light.

The current density determines the amount of oxidizing agents in EAOPs $[9,15,16]$ and then, the influence of this parameter on the mineralization rate of the drug solution was examined for the most powerful system, namely PEF with a BDD anode. As expected, Fig. 2d shows an enhancement of TOC removal with increasing $j$, which was more apparent when raising from 10 to $25 \mathrm{~mA} \mathrm{~cm}{ }^{-2}$. This can be explained by the simultaneous acceleration of reaction (1) to produce larger amounts of $\operatorname{BDD}\left({ }^{\bullet} \mathrm{OH}\right)$ and reaction (2) to generate a greater quantity of $\mathrm{H}_{2} \mathrm{O}_{2}$ that further ends in larger amounts of $\bullet \mathrm{OH}$ via Fenton's reaction (4). Under these conditions, $\mathrm{Fe}^{2+}$ is more rapidly regenerated from reaction (5) to enhance ${ }^{\bullet} \mathrm{OH}$ production. Moreover, organics are more rapidly oxidized to yield photoactive species that, in turn, are more quickly photodegraded by UVA light and cause a greater TOC removal. At the end of these trials, $87 \%, 90 \%$ and $91 \%$ mineralization was attained at 10,25 and $50 \mathrm{~mA} \mathrm{~cm}^{-2}$, 
respectively. Based on the similar TOC-time profiles obtained at 25 and $50 \mathrm{~mA} \mathrm{~cm}{ }^{-2}$ (see Fig. 2d), the former value can be considered as the optimum $j$ for PEF with a BDD anode. A similar trend is expected for the comparative PEF treatments with $\mathrm{Pt}, \mathrm{IrO}_{2}$-based and $\mathrm{RuO}_{2}$ based anodes since an analogous enhancement can be plausibly hypothesized in such systems when increasing $j[15,16]$, although with lower mineralization ability due to the smaller oxidization power of their physisorbed $\mathrm{M}\left({ }^{\bullet} \mathrm{OH}\right)$ compared with $\mathrm{BDD}\left({ }^{\bullet} \mathrm{OH}\right)$.

\subsection{Mineralization current efficiency and specific energy consumption}

The mineralization current efficiency for the above trials calculated from Eq. (8) is presented in Fig. 3a-d. The MCE values at $j=50 \mathrm{~mA} \mathrm{~cm}^{-2}$ rose with the oxidation power of the EAOPs, always increasing in the sequence: EO- $\mathrm{H}_{2} \mathrm{O}_{2}<\mathrm{EF}<\mathrm{PEF}$, regardless of the anode used. In the case of EO- $\mathrm{H}_{2} \mathrm{O}_{2}$, a very small current efficiency was found with Pt owing to its low oxidation ability (see Fig. 3a), whereas it attained an initial value of about $20-22 \%$ with the other anodes that finally dropped to about $2.5-2.8 \%$ using the $\mathrm{RuO}_{2}$-based (see Fig. 3c) and BDD (see Fig. 3d) and to a higher value of $4.0 \%$ using the $\mathrm{IrO}_{2}$-based one (see Fig. 4d). In EF, Pt yielded again the lowest MCE values, which decayed from 13.3\% at 20 min to 4.4\% at 360 min (see Fig. 3a). In contrast, similar final current efficiencies near 5.3\% were obtained with the other three anodes (see Fig. 3c-d) since they led to analogous TOC abatement. Fig. 3a-d also shows that the greatest MCE values for each anode were found for the most potent process, i.e., PEF. At 120 min of this treatment, when almost maximum mineralization was attained, about 25-26\% current efficiency was achieved with $\mathrm{Pt}, \mathrm{RuO}_{2}$-based and $\mathrm{IrO}_{2}$-based anodes, whereas near 28\% was obtained using BDD anode, further being reduced to $10.2 \%$ at $360 \mathrm{~min}$. These results confirm that the synergistic combination of $\operatorname{BDD}\left({ }^{\bullet} \mathrm{OH}\right),{ }^{\bullet} \mathrm{OH}$ and UVA light in PEF with a BDD/air-diffusion cell leads to the most efficient mineralization of the 40 mg $\mathrm{L}^{-1}$ NPX sodium solution. It is also noticeable the progressive decay of MCE with prolonging electrolysis in all the trials shown in Fig. 3a-d. This loss in current efficiency can 
be ascribed to the gradual decrease in organic matter load as well as the formation of recalcitrant products, which makes the EAOPs much more inefficient over time $[9,15]$.

The effect of $j$ on the MCE values determined for PEF process with a BDD anode are also depicted in Fig. 3d. A gradual drop in current efficiency with raising $j$ from 10 to $50 \mathrm{~mA}$ $\mathrm{cm}^{-2}$ can be observed. At $120 \mathrm{~min}$, for example, MCE values of 53.1\%, 49.1\% and 28.0\% were determined at 10,25 and $50 \mathrm{~mA} \mathrm{~cm}^{-2}$, respectively, which diminished up to $40.1 \%$, $19.2 \%$ and $10.2 \%$ at $360 \mathrm{~min}$. The fall in current efficiency at greater $j$ can be related to the quicker acceleration of parasitic non-oxidizing reactions of generated hydroxyl radicals with the consequent deceleration of organics oxidation. Among them, the most important parasitic reaction is the anodic oxidation of $\operatorname{BDD}\left({ }^{\bullet} \mathrm{OH}\right)$ to $\mathrm{O}_{2}$ from reaction (11), whereas less significant reactions involve the dimerization of ${ }^{\bullet} \mathrm{OH}$ to $\mathrm{H}_{2} \mathrm{O}_{2}$ and its destruction by $\mathrm{H}_{2} \mathrm{O}_{2}$ and $\mathrm{Fe}^{2+}$ from reactions (12)-(14), respectively [9,15,16,39,45]:

$$
\begin{aligned}
& \left.2 \mathrm{BDD}\left({ }^{\circ} \mathrm{OH}\right)\right) \rightarrow 2 \mathrm{BDD}+\mathrm{O}_{2}+2 \mathrm{H}^{+}+2 \mathrm{e}^{-} \\
& 2{ }^{\circ} \mathrm{OH} \rightarrow \mathrm{H}_{2} \mathrm{O}_{2} \\
& \mathrm{H}_{2} \mathrm{O}_{2}+{ }^{\circ} \mathrm{OH} \rightarrow \mathrm{HO}_{2}^{\cdot}+\mathrm{H}_{2} \mathrm{O} \\
& \mathrm{Fe}^{2+}+\cdot{ }^{\circ} \mathrm{OH} \rightarrow \mathrm{Fe}^{3+}+\mathrm{OH}^{-}
\end{aligned}
$$

On the other hand, the change of $\mathrm{EC}_{\text {тос }}$ calculated from Eq. (9) with electrolysis time for the assays of Fig. 2a-d at $j=50 \mathrm{~mA} \mathrm{~cm}^{-2}$ are presented in Fig. 4a-d, respectively. It is evident that lower TOC removal, which entailed a poorer current efficiency, yielded greater specific consumption. The EO- $\mathrm{H}_{2} \mathrm{O}_{2}$ treatments were then the most expensive in all cases, particularly using Pt that yielded $\mathrm{EC}_{\mathrm{TOC}}$ values as high as $21 \mathrm{kWh}(\mathrm{g} \mathrm{TOC})^{-1}$ at $360 \mathrm{~min}$ (not shown in Fig. 4a). For all the processes, an almost linear increase of $\mathrm{EC}_{\mathrm{TOC}}$ over time can be observed in Fig. 4a-d. The lowest specific energy consumptions for all the EAOPs tested were obtained with the $\mathrm{IrO}_{2}$-based anode, with similar values in EF and PEF using the $\mathrm{RuO}_{2}$-based one and 
close results to those with Pt in PEF. Conversely, with BDD, higher ECTOC values compared to those with $\mathrm{IrO}_{2}$-based anode were always found, even in PEF despite yielding the largest mineralization, owing to the greater $E_{\text {cell }}$ of the BDD/air-diffusion cell. For example, at 120 min of PEF treatments, about $0.59 \mathrm{kWh}\left(\mathrm{g}\right.$ TOC) ${ }^{-1}$ was consumed using $\mathrm{Pt}$, $\mathrm{IrO}_{2}$-based and $\mathrm{RuO}_{2}$-based anodes and a higher consumption of $0.71 \mathrm{kWh}\left(\mathrm{g}\right.$ TOC) ${ }^{-1}$ was needed with BDD. It should be mentioned that the energy consumption related to the UVA lamp was not considered in PEF since free sunlight can be alternatively employed as energy source [15]. Fig. 4d also highlights the expected decay of $\mathrm{EC}_{\text {Tос }}$ with decreasing $j$ from 50 to $10 \mathrm{~mA} \mathrm{~cm}{ }^{-2}$. For the best process, namely PEF with a BDD anode at $j=25 \mathrm{~mA} \mathrm{~cm}^{-2}, \mathrm{EC}_{\mathrm{TOC}}=0.69 \mathrm{kWh}(\mathrm{g}$ $\mathrm{TOC}^{-1}$ was found at $240 \mathrm{~min}$, which increased up to $1.01 \mathrm{kWh}\left(\mathrm{g}\right.$ TOC) ${ }^{-1}$ at $360 \mathrm{~min}$ when 91\% mineralization and 19.2\% current efficiency were reached.

\subsection{Decay of NPX concentration}

The kinetics of the reaction between NPX and hydroxyl radicals $\left(\mathrm{M}\left({ }^{\bullet} \mathrm{OH}\right)\right.$ and/or $\left.{ }^{\bullet} \mathrm{OH}\right)$ in the EAOPs tested was followed by reversed-phase HPLC. A blank experiment with recirculation of $2.5 \mathrm{~L}$ of a $40 \mathrm{mg} \mathrm{L}^{-1} \mathrm{NPX}$ sodium solution in $0.050 \mathrm{M} \mathrm{NaClO}_{4}$ at $\mathrm{pH} 3.0$ in the flow plant under irradiation with the UVA lamp did not show any change in the concentration of the drug, meaning that it is photostable and its oxidation in all the EAOPs is mainly due to the action of generated hydroxyl radicals.

Fig. 5a depicts the rapid decay of the normalized NPX concentration in the EF and PEF treatments of the $0.174 \mathrm{mM}$ drug solution using a BDD anode at $j=50 \mathrm{~mA} \mathrm{~cm}{ }^{-2}$. The data for the analogous $\mathrm{EO}-\mathrm{H}_{2} \mathrm{O}_{2}$ process (without $\mathrm{Fe}^{2+}$ ) are not presented because its decay kinetics was much slower, which confirms the preeminent oxidizing role of ${ }^{\bullet} \mathrm{OH}$ in the bulk in EF and PEF. As can be seen, NPX disappeared in 12 min by EF and at a time slightly shorter of 10 min by PEF. The quicker destruction of the drug in the latter process can be related to the additional generation of $\bullet \mathrm{OH}$ induced by the photolytic reaction (5) under UVA irradiation. 
This corroborates that the pale yellow color reached after few minutes of EF and PEF is due to the formation of $\mathrm{Fe}(\mathrm{III})$ complexes of some products, as proposed above. The NPX concentration decay for both processes obeyed a pseudo-first-order kinetics, as can be seen in the inset panel of Fig. 5a. From this behavior, a pseudo rate constant $\left(k_{1}\right)$ of $5.2 \times 10^{-3} \mathrm{~s}^{-1}$ (square regression coefficient, $\left.R^{2}=0.994\right)$ for EF and $6.4 \times 10^{-3} \mathrm{~s}^{-1}\left(R^{2}=0.998\right)$ for PEF was determined. This behavior suggests the reaction of NPX with a constant amount of hydroxyl radicals.

Fig. 5a also shows an increasing abatement of normalized NPX content when $j$ varies from 10 to $50 \mathrm{~mA} \mathrm{~cm}^{-2}$ for PEF with a BDD anode. These data always followed a pseudofirst-order kinetics (see the inset panel of Fig. 5a), with raising $k_{1}$ values of $1.4 \times 10^{-3} \mathrm{~s}^{-1}\left(R^{2}=\right.$ 0.995), $2.1 \times 10^{-3} \mathrm{~s}^{-1}\left(R^{2}=0.990\right)$ and $6.4 \times 10^{-3} \mathrm{~s}^{-1}\left(R^{2}=0.998\right)$ at 10,25 and $50 \mathrm{~mA} \mathrm{~cm}{ }^{-2}$, respectively. This trend can be again associated with the greater generation of $\bullet \mathrm{OH}$ from reactions (4) and (5) as $j$ increased.

On the other hand, Fig. 5b exemplifies the drop of the normalized NPX concentration under PEF conditions using $\mathrm{Pt}$, $\mathrm{IrO}_{2}$-based and $\mathrm{RuO}_{2}$-based anodes at $j=50 \mathrm{~mA} \mathrm{~cm}{ }^{-2}$, also obeying a pseudo-first-order kinetics with respective $k_{1}$ values of $3.1 \times 10^{-3} \mathrm{~s}^{-1}\left(R^{2}=0.997\right)$, $8.4 \times 10^{-3} \mathrm{~s}^{-1}\left(R^{2}=0.991\right)$ and $2.0 \times 10^{-3} \mathrm{~s}^{-1}\left(R^{2}=0.987\right)$. Comparison with Fig. 5a allows inferring that NPX oxidation rate depended on the anode used, being increasingly favored in the sequence: $\mathrm{RuO}_{2}$-based $<\mathrm{Pt}<\mathrm{BDD}<\mathrm{IrO}_{2}$-based. This tendency shows a clear influence of the anode material, suggesting a small participation of its generated $\mathrm{M}\left({ }^{\bullet} \mathrm{OH}\right)$ radicals during the destruction of the drug. It differs from the relative TOC decay found or PEF, where BDD was the most effective anode (see Fig. 2a-d), since this parameter evaluates the mineralization of intermediates by hydroxyl radicals and UVA irradiation, showing different reactivity than the parent molecule. Our PEF results are better than those reported for the photo-Fenton degradation of NPX at neutral $\mathrm{pH}$, which needed about 30 min to remove $30 \mu \mathrm{g} \mathrm{L}^{-1}$ of this 
drug and other 31 emergent pollutants from a WWTF effluent using $5 \mathrm{mg} \mathrm{L}^{-1}$ of $\mathrm{Fe}^{2+}$ and 50 mg L $\mathrm{L}^{-1}$ of $\mathrm{H}_{2} \mathrm{O}_{2}$ under UVC $\left(\lambda_{\max }=254 \mathrm{~nm}\right)$ and solar irradiation [27].

\subsection{Identification of aromatic intermediates and generated carboxylic acids}

Several short treatments of $2.5 \mathrm{~L}$ of $40 \mathrm{mg} \mathrm{L}^{-1} \mathrm{NPX}$ sodium solutions were performed by EO- $\mathrm{H}_{2} \mathrm{O}_{2}$ and EF using a BDD anode at $j=50 \mathrm{~mA} \mathrm{~cm}{ }^{-2}$. The six aromatic by-products determined by means of GC-MS from the organic fraction extracted from the electrolyzed solutions are shown in Fig. 6, which presents a plausible sequence for their formation from NPX (compound 1) in all the EAOPs tested. The process is initiated by the hydroxylation of the methyl position of $\mathbf{1}$ upon attack by $\mathrm{M}\left({ }^{\bullet} \mathrm{OH}\right)$ and/or ${ }^{\bullet} \mathrm{OH}$ to yield 2-methoxy-6vinylnaphthalene (compound 2) and 2-acetyl-6-methoxynaphthalene (compound 3), which are sequentially oxidized to 6-methoxy-2-naphthoic acid (compound 4). Parallel hydroxylation of compound 3 with demethylation leads to 1-(6-hydroxynaphthalen-2-yl)ethanone (compound 5) that can be subsequently hydroxylated to compound 6. Further degradation of the above naphthalene derivatives with opening of one benzenic ring gives phthalic acid (compound 7) as final aromatic by-product. The mass spectra of NPX and its six detected by-products are shown in Fig. SM-2 of Supplementary Material. Note that Chin et al. [6] also found the compound 3, along with 2-(6-hydroxy-2-naphtyl)propanoic acid, as major intermediates during the EO of NPX solutions using Pt and Pt/MWCNTs particles on FTO glasses as anodes.

On the other hand, ion-exclusion HPLC of electrolyzed solutions revealed the formation of short-linear carboxylic acids like maleic and oxalic. These acids proceed from the consecutive cleavage of the above aromatic by-products, being oxalic acid the last compound formed because it is directly transformed into $\mathrm{CO}_{2}[35,38-40]$. Concentrations $<1 \mathrm{mg} \mathrm{L}^{-1}$ were always detected for maleic acid, which disappeared at times shorter than $300 \mathrm{~min}$. In contrast, oxalic acid was accumulated to a much larger extent, except for $\mathrm{EO}-\mathrm{H}_{2} \mathrm{O}_{2}$ where it 
was not practically detected due to the low mineralization achieved in all cases (see Fig. 2). Fig. 7 shows the time course of this acid during the EF and PEF treatments of $2.5 \mathrm{~L}$ of $40 \mathrm{mg}$ $\mathrm{L}^{-1} \mathrm{NPX}$ sodium solutions with $0.50 \mathrm{mM} \mathrm{Fe}^{2+}$ at $\mathrm{pH} 3.0$ in a BDD/air-diffusion cell at $j=50$ $\mathrm{mA} \mathrm{cm}^{-2}$, where final Fe(III)-oxalate complexes are largely formed [37]. For the EF process, oxalic acid underwent gradual accumulation up to reach $23.2 \mathrm{mg} \mathrm{L}^{-1}$, as expected if Fe(III)oxalate are hardly degraded by hydroxyl radicals. This content represents $6.20 \mathrm{mg} \mathrm{L}^{-1} \mathrm{TOC}$ that corresponds to $44 \%$ of the remaining $14.1 \mathrm{mg} \mathrm{L}^{-1}$ TOC of the final solution (see Fig. $2 \mathrm{~d}$ ). This means that the application of EF generates a large proportion of products that are even more recalcitrant than short-linear carboxylic acids. Conversely, Fig. 7 evidences that oxalic acid disappears in less than 180 min by PEF, as a result of the fast photolysis of its Fe(III) complexes by UVA light via reaction (6). Moreover, the synergistic action of this radiation also enhanced the destruction of several recalcitrant intermediates, reducing the final solution TOC up to $2.49 \mathrm{mg} \mathrm{L}^{-1}$ (see Fig. 2d). This explains the superiority of PEF over EF to mineralize NPX.

\section{Conclusions}

This work demonstrates the fundamental role of the anode material to determine the performance of EAOPs. Solutions containing NPX have been degraded using a flow plant with a filter-press cell. The oxidation power of the processes increased in the order: $\mathrm{EO}-\mathrm{H}_{2} \mathrm{O}_{2}$ $<\mathrm{EF}<\mathrm{PEF}$ at $50 \mathrm{~mA} \mathrm{~cm}^{-2}$, regardless of the anode material, although they showed different characteristics in terms of TOC removal, mineralization current efficiency and specific energy consumption. Pt was the worst choice for $\mathrm{EO}-\mathrm{H}_{2} \mathrm{O}_{2}$ and $\mathrm{EF}$, yielding low mineralization. In contrast, the $\mathrm{IrO}_{2}$-based anode led to the largest mineralization in both treatments, performing better than the $\mathrm{RuO}_{2}$-based anode. The $\mathrm{BDD}$ anode yielded an almost total mineralization of 91\% in PEF, slightly better than 85\% found with the other three anodes. Cheap DSA anodes 
can then be successfully used for the degradation of NPX in water. The decrease in $j$ yielded higher current mineralization and lower specific energy consumption and thus, the optimum treatment was PEF with a BDD anode at $25 \mathrm{~mA} \mathrm{~cm}^{-2}$, yielding 90\% mineralization, $19.2 \%$ current mineralization and $\mathrm{EC}_{\mathrm{TOC}}=1.01 \mathrm{kWh}(\mathrm{g} \text { TOC})^{-1}$ at 360 min. The NPX concentration decay always obeyed a pseudo-first-order kinetics. In PEF, this decay became faster in the sequence: $\mathrm{RuO}_{2}$-based $<\mathrm{Pt}<\mathrm{BDD}<\mathrm{IrO}_{2}$-based, confirming a strong influence of the anode nature on the $\mathrm{M}\left({ }^{\bullet} \mathrm{OH}\right)$-mediated destruction of NPX and its intermediates. Up to six aromatic products and short-linear carboxylic acids like maleic and oxalic were identified. The Fe(III)oxalate complexes were not removed in EF, but its fast decomposition under UVA irradiation explained the almost total mineralization achieved by PEF with a BDD anode.

\section{Acknowledgments}

The authors would like to thank the following organizations for their financial support: CONACYT (Mexico), under project 240522, MINECO (Spain) under project CTQ201348897-C2-1-R, co-financed with FEDER funds, and Universidad de Guanajuato. G. Coria is grateful to CONACYT for the scholarship No. 366128 granted.

\section{References}

[1] O. Golovko, V. Kumar, G. Fedorova, T. Randak, R. Grabic, Seasonal changes in antibiotics, antidepressants/psychiatric drugs, antihistamines and lipid regulators in a wastewater treatment plant, Chemosphere 111 (2014) 418-426.

[2] J. Rivera-Utrilla, M. Sánchez-Polo, M.A. Ferro-García, G. Prados-Joya, R. OcampoPérez, Pharmaceuticals as emerging contaminants and their removal from water. A review, Chemosphere 93 (2013) 1268-1287. 
[3] L. Feng, E.D. van Hullebusch, M.A. Rodrigo, G. Esposito, M.A. Oturan, Removal of residual anti-inflammatory and analgesic pharmaceuticals from aqueous systems by electrochemical advanced oxidation processes. A review, Chem. Eng. J. 228 (2013) 944-964.

[4] I. Sirés, E. Brillas, Remediation of water pollution caused by pharmaceutical residues based on electrochemical separation and degradation technologies: A review, Environ. Int. 40 (2012) 212-229.

[5] E. Brillas, I. Sirés, Electrochemical removal of pharmaceuticals from water streams: Reactivity elucidation by mass spectrometry, Trends Anal. Chem. 70 (2015) 112-121.

[6] C.-J.M. Chin, T.-Y. Chen, M. Lee, C.-F. Chang, Y.-T. Liu, Y.-T. Kuo, Effective anodic oxidation of naproxen by platinum nanoparticles coated FTO glass, J. Hazard. Mater. 277 (2014) 110-119.

[7] B.R. Garza-Campos, J.L. Guzmán-Mar, L. Hinojosa Reyes, E. Brillas, A. HernándezRamírez, E.J. Ruiz-Ruiz, Coupling of solar photoelectro-Fenton with a BDD anode and solar heterogeneous photocatalysis for the mineralization of the herbicide atrazine, Chemosphere 97 (2014) 26-33.

[8] A. Thiam, I. Sirés, J.A. Garrido, R.M. Rodríguez, E. Brillas, Effect of anions on electrochemical degradation of azo dye Carmoisine (Acid Red 14) using a BDD anode and air-diffusion cathode, Sep. Purif. Technol. 140 (2015) 43-52.

[9] M. Panizza, G. Cerisola, Direct and mediated anodic oxidation of organic pollutants, Chem. Rev. 109 (2009) 6541-6569.

[10] M. Panizza, G. Cerisola, Olive mill wastewater treatment by anodic oxidation with parallel plate electrodes, Water Res. 40 (2006) 1179-1184. 
[11] J. Ribeiro, F.L.S. Purgato, K.B. Kokoh, J.-M. Léger, A.R. De Andrade, Application of $\mathrm{Ti} / \mathrm{RuO}_{2}-\mathrm{Ta}_{2} \mathrm{O}_{5}$ electrodes in the electrooxidation of ethanol and derivants: reactivity versus electrocatalytic efficiency, Electrochim. Acta 53 (2008) 7845-7851.

[12] O. Scialdone, S. Randazzo, A. Galia, G. Filardo, Electrochemical oxidation of organics at metal oxide electrode: the incineration of oxalic acid at $\mathrm{IrO}_{2}-\mathrm{Ta}_{2} \mathrm{O}_{5}\left(\mathrm{DSA}-\mathrm{O}_{2}\right)$ anode, Electrochim. Acta 54 (2009) 1210-1217.

[13] B. Borbón, M.T. Oropeza-Guzman, E. Brillas, I. Sirés, Sequential electrochemical treatment of dairy wastewater using aluminium and DSA-type anodes, Environ. Sci. Pollut. Res. 21 (2014) 8573-8584.

[14] C. Salazar, I. Sirés, R. Salazar, H. Mansilla, C.A. Zaror, Treatment of cellulose bleaching effluents and their filtration permeates by anodic oxidation with $\mathrm{H}_{2} \mathrm{O}_{2}$ production, J. Chem. Technol. Biotechnol. 90 (2015) 2017-2026.

[15] I. Sirés, E. Brillas, M.A. Oturan, M.A. Rodrigo, M. Panizza, Electrochemical advanced oxidation processes: today and tomorrow. A review, Environ. Sci. Pollut. Res. 21 (2014) 8336-8367.

[16] S. Vasudevan, M.A. Oturan, Electrochemistry: As cause and cure in water pollution-an overview, Environ. Chem. Lett. 12 (2014) 97-108.

[17] A. Dirany, I. Sirés, N. Oturan, A. Özcan, M.A. Oturan, Electrochemical treatment of the antibiotic sulfachloropyridazine: kinetics, reaction pathways, and toxicity evolution. Environ. Sci. Technol. 46 (2012) 4074-4082.

[18] A. El-Ghenymy, R.M. Rodríguez, E. Brillas, N. Oturan, M.A. Oturan, Electro-Fenton degradation of the antibiotic sulfanilamide with Pt/carbon-felt and BDD/carbon-felt cells. Kinetics, reaction intermediates, and toxicity assessment, Environ. Sci. Pollut. Res. 21 (2014) 8368-8378. 
[19] G. Coria, T. Pérez, I. Sirés, J.L. Nava, Mass transport studies during dissolved oxygen reduction to hydrogen peroxide in a filter-press electrolyzer using graphite felt, reticulated vitreous carbon and boron-doped diamond as cathodes, J. Electroanal. Chem, 757 (2015) 225-229.

[20] F.C. Moreira, S. Garcia-Segura, R.A.R. Boaventura, E. Brillas, V.J.P. Vilar, Degradation of the antibiotic trimethoprim by electrochemical advanced oxidation processes using a carbon-PTFE air-diffusion cathode and a boron-doped diamond or platinum anode, Appl. Catal. B: Environ. 160-161 (2014) 492-505.

[21] C. Flox, J.A. Garrido, R.M. Rodríguez, P.L. Cabot, F. Centellas, C. Arias, E. Brillas, Mineralization of herbicide mecoprop by photoelectro-Fenton with UVA and solar light, Catal. Today 129 (2007) 29-36.

[22] Z. Yu, S. Peldszus, P.M. Huck, Adsorption characteristics of selected pharmaceuticals and an endocrine disrupting compound -Naproxen, carbamazepine and nonylphenol- on activated carbon, Water Res. 42 (2008) 2873-2882.

[23] Y. Önal, C. Akmil-Bas, C. Sarıcı-Özdemir, Elucidation of the naproxen sodium adsorption onto activated carbon prepared from waste apricot: kinetic, equilibrium and thermodynamic characterization, J. Hazard. Mater. 148 (2007) 727-734.

[24] R. Marotta, D. Spasiano, I. Di Somma, R. Andreozzi, Photodegradation of naproxen and its photoproducts in aqueous solution at $254 \mathrm{~nm}$ : a kinetic investigation, Water Res. 47 (2012) 373-383.

[25] R. Katalin, Degradation of naproxen by UV, photolysis and their combination, J. Hazard. Mater. 262 (2013) 151-157.

[26] R. Rosal, A. Rodríguez, M.S. Gonzalo, E. García-Calvo, Catalytic ozonation of naproxen and carbamazepine on titanium dioxide, Appl. Catal. B: Environ. 84 (2008) 48-57. 
[27] N. De la Cruz, J. Giménez, S. Esplugas, D. Grandjean, L.F. de Alencastro, C. Pulgarín, Degradation of 32 emergent contaminants by UV and neutral photo-Fenton in domestic wastewater effluent previously treated by activated sludge, Water. Res. 46 (2012) 19471957.

[28] D. Kanakaraju, C.A. Motti, B.D. Glass, M. Oelgemölle, $\mathrm{TiO}_{2}$ photocatalysis ofnaproxen: Effect of the water matrix, anions and diclofenac on degradation rates, Chemosphere 139 (2015) 579-588.

[29] R.J. Lan, J.T. Li, H.W. Sun, W.B. Su, Degradation of naproxen by combination of Fenton reagent and ultrasound irradiation: optimization using response surface methodology, Water Sci. Technol. 66 (2012) 2695-2701.

[30] J.-K. Im, J. Yoon, N. Her, J. Han, K.-D. Zoh, Y. Yoon, Sonocatalytic-TiO 2 nanotube, Fenton, and $\mathrm{CCl}_{4}$ reactions for enhanced oxidation, and their applications to acetaminophen and naproxen degradation, Sep. Purif. Technol. 141 (2015) 1-9.

[31] T. González, J.R. Domínguez, P. Palo, J. Sánchez-Martín, Conductive-diamond electrochemical advanced oxidation of naproxen in aqueous solution: optimizing the process, J. Chem. Technol. Biotechnol. 86 (2011) 121-127.

[32] X. Zhao, J. Qu, H. Liu, Z. Qiang, R. Liu, C. Hu, Photoelectrochemical degradation of anti-inflammatory pharmaceuticals at $\mathrm{Bi}_{2} \mathrm{MoO}_{6}$-boron-doped diamond hybrid electrode under visible light irradiation, Appl. Catal. B: Environ. 91 (2009) 539-545.

[33] A. Wang, Y.-Y. Li, A.L. Estrada, Mineralization of antibiotic sulfamethoxazole by photoelectro-Fenton treatment using activated carbon fiber cathode and under UVA irradiation, Appl. Catal. B: Environ. 102 (2011) 378-386.

[34] A. Thiam, M. Zhou, E. Brillas, I. Sirés, A first pre-pilot system for the combined treatment of dye pollutants by electrocoagulation/EAOPs, J. Chem. Technol. Biotechnol. 89 (2014) 1136-1144. 
[35] H. Olvera-Vargas, N. Oturan, E. Brillas, D. Buisson, G. Esposito, M.A. Oturan, Electrochemical advanced oxidation for cold incineration of the pharmaceutical ranitidine: Mineralization pathway and toxicity evolution, Chemosphere 117 (2014) 644-651.

[36] E. Mousset, N. Oturan, E.D. van Hullebusch, G. Guibaud, G. Esposito, M.A. Oturan, Treatment of synthetic soil washing solutions containing phenanthrene and cyclodextrin by electro-oxidation. Influence of anode materials on toxicity removal and biodegradability enhancement, Appl. Catal. B: Environ. 160-161 (2014) 666-675.

[37] I. Sirés, E. Brillas, G. Cerisola, M. Panizza, Comparative depollution of mecoprop aqueous solutions by electrochemical incineration using $\mathrm{BDD}$ and $\mathrm{PbO}_{2}$ as high oxidation power anodes, J. Electroanal. Chem. 613 (2008) 151-159

[38] E.J. Ruiz, A. Hernández-Ramírez, J.M. Peralta-Hernández, C. Arias, E. Brillas, Application of solar photoelectro-Fenton technology to azo dyes mineralization: Effect of current density, $\mathrm{Fe}^{2+}$ and dye concentration, Chem. Eng. J. 171 (2011) 385-392.

[39] R. Salazar, E. Brillas, I. Sirés, Finding the best $\mathrm{Fe}^{2+} / \mathrm{Cu}^{2+}$ combination for the solar photoelectro-Fenton treatment of simulated wastewater containing the industrial textile dye Disperse Blue 3, Appl. Catal. B: Environ. 115-116 (2012) 107-116.

[40] A.R.F. Pipi, A.R. De Andrade, E. Brillas, I. Sirés, Total removal of alachlor from water by electrochemical processes, Sep. Purif. Technol. 132 (2014) 674-683.

[41] E. Brillas, J.C. Calpe, J. Casado, Mineralization of 2,4-D by advanced electrochemical oxidation processes, Water Res. 34 (2000) 2253-2262.

[42] V.M Vasconcelos, C. Ponce-de-León, J.L. Nava, M.R.V. Lanza, Electrochemical degradation of RB-5 dye by anodic oxidation, electro-Fenton and by combining anodic oxidation-electro-Fenton in a filter press flow cell, J. Electroanal. Chem. 765 (2016) 179-187. 
[43] E. Guinea, C. Arias, P.L. Cabot, J.A. Garrido, R.M. Rodríguez, F. Centellas, E. Brillas, Mineralization of salicylic acid in acidic aqueous medium by electrochemical advanced oxidation processes using platinum and boron-doped diamond as anode and cathodically generated hydrogen peroxide, Water. Res. 42 (2008) 499-511.

[44] M.I. León, Z.G. Aguilar, J.L. Nava, Electrochemical combustion of indigo at ternary oxide coated titanium anodes, J. Electrochem. Sci. Eng. 4(4) (2014) 247-258.

[45] J.L. Nava, F. Núñez, I. González, Electrochemical incineration of $p$-cresol and $o$-cresol in the filter-press-type FM01-LC electrochemical cell using BDD electrodes in sulfate media at pH 0, Electrochim. Acta. 52 (2007) 3229-3235. 


\section{Figure captions}

Fig. 1. Change of the accumulated $\mathrm{H}_{2} \mathrm{O}_{2}$ concentration with electrolysis time for the treatment of $2.5 \mathrm{~L}$ of a $0.050 \mathrm{M} \mathrm{NaClO}_{4}$ solution at $\mathrm{pH} 3.0$ and $35{ }^{\circ} \mathrm{C}$ using a flow plant equipped with a filter-press cell with electrodes of $20 \mathrm{~cm}^{2}$ coupled with an annular glass photoreactor of 640 $\mathrm{mL}$ irradiated volume at $j$ of $50 \mathrm{~mA} \mathrm{~cm}{ }^{-2}$ and liquid flow rate of $180 \mathrm{~L} \mathrm{~h}^{-1}$. An air-diffusion carbon-PTFE cathode was always employed. In (a), use of (O) Pt and ( $)$ BDD as anode, in the absence of $\mathrm{Fe}^{2+}$. In (b), $0.50 \mathrm{mM} \mathrm{Fe}{ }^{2+}$ was added to the solution using a ( $\square$ ) $\mathrm{Pt},(\triangle) \mathrm{IrO}_{2^{-}}$ based, $(\nabla) \mathrm{RuO}_{2}$-based and ( $\left.\boldsymbol{\square}\right)$ BDD anode. In photoassisted trials, the photoreactor was irradiated with a $160 \mathrm{~W}$ UVA lamp placed inside, and a $(\diamond)$ Pt or $(\diamond)$ BDD anode was used.

Fig. 2. Variation of normalized TOC with electrolysis time for the degradation of $2.5 \mathrm{~L}$ of 40 mg L ${ }^{-1}$ naproxen sodium (26 mg L ${ }^{-1}$ TOC) solutions in $0.050 \mathrm{M} \mathrm{NaClO}_{4}$ at $\mathrm{pH} 3.0$ and $35{ }^{\circ} \mathrm{C}$ using a flow plant with an anode of (a) Pt, (b) $\mathrm{IrO}_{2}$-based, (c) $\mathrm{RuO}_{2}$-based and (d) $\mathrm{BDD}$ at liquid flow rate of $180 \mathrm{~L} \mathrm{~h}^{-1}$. (O) Electrochemical oxidation with electrogenerated $\mathrm{H}_{2} \mathrm{O}_{2}$ (EO$\mathrm{H}_{2} \mathrm{O}_{2}$ ), ( $\square$ ) electro-Fenton (EF) with $0.50 \mathrm{mM} \mathrm{Fe}{ }^{2+}$ and (ם) photoelectro-Fenton (PEF) with $0.50 \mathrm{mM} \mathrm{Fe}^{2+}$ under a $160 \mathrm{~W}$ UVA irradiation. Current density: (A) $10 \mathrm{~mA} \mathrm{~cm}{ }^{-2}$ and $(\boldsymbol{\nabla}) 25$

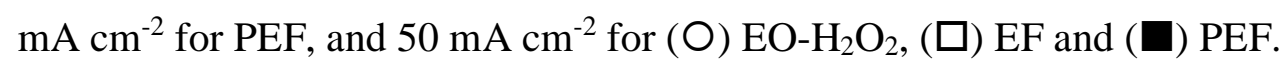

Fig. 3. Profiles of mineralization current efficiency estimated from Eq. (8) with electrolysis time for the trials of Fig. 2.

Fig. 4. Specific energy consumption per unit TOC mass calculated from Eq. (9) vs. electrolysis time for the experiments shown in Fig. 2.

Fig. 5. Evolution of normalized naproxen concentration during the treatment of $2.5 \mathrm{~L}$ of 40 $\mathrm{mg} \mathrm{L}^{-1}(0.174 \mathrm{mM})$ naproxen sodium in $0.050 \mathrm{M} \mathrm{NaClO}_{4}$ with $0.50 \mathrm{mM} \mathrm{Fe}^{2+}$ at $\mathrm{pH} 3.0$ and $35{ }^{\circ} \mathrm{C}$ using a flow plant at liquid flow rate of $180 \mathrm{~L} \mathrm{~h}^{-1}$. (a) (•) EF at $50 \mathrm{~mA} \mathrm{~cm}^{-2}$ and PEF at 
(A) $10 \mathrm{~mA} \mathrm{~cm}^{-2}$, ( $\left.\boldsymbol{\nabla}\right) 25 \mathrm{~mA} \mathrm{~cm}^{-2}$ and (ם) $50 \mathrm{~mA} \mathrm{~cm}^{-2}$ using a BDD anode. (b) PEF process at $50 \mathrm{~mA} \mathrm{~cm}{ }^{-2}$ using an anode of $(\diamond) \mathrm{Pt},(\triangle) \mathrm{IrO}_{2}$-based and $(\nabla) \mathrm{RuO}_{2}$-based.

Fig. 6. Proposed reaction pathway for the initial degradation of naproxen by electrochemical advanced oxidation processes. The main oxidants are $\mathrm{M}\left({ }^{\bullet} \mathrm{OH}\right)$ formed at the anode $\mathrm{M}$ from water oxidation in $\mathrm{EO}-\mathrm{H}_{2} \mathrm{O}_{2}$, along with ${ }^{\circ} \mathrm{OH}$ produced from Fenton's reaction in EF and PEF.

Fig. 7. Time course of oxalic acid concentration detected during the mineralization of $2.5 \mathrm{~L}$ of $40 \mathrm{mg} \mathrm{L}^{-1}$ naproxen sodium in $0.050 \mathrm{M} \mathrm{NaClO}_{4}$ with $0.50 \mathrm{mM} \mathrm{Fe}{ }^{2+}$ at $\mathrm{pH} 3.0$ and $35{ }^{\circ} \mathrm{C}$ using a flow plant with a BDD/air-diffusion cell at $50 \mathrm{~mA} \mathrm{~cm}^{-2}$ and liquid flow rate of $180 \mathrm{~L} \mathrm{~h}^{-1}$. Method: ( $\square$ ) EF and ( $\square$ ) PEF. 


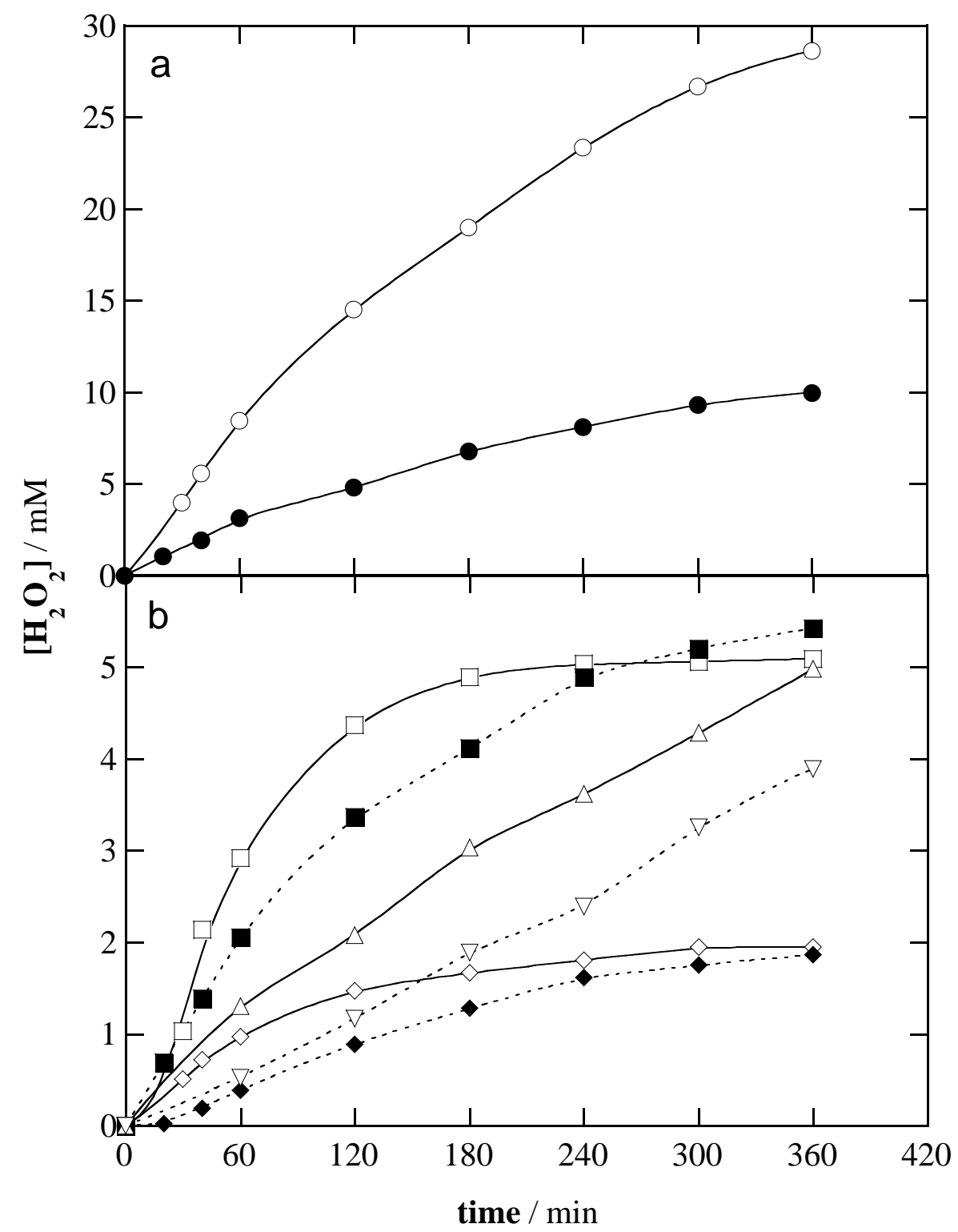

Fig. 1 


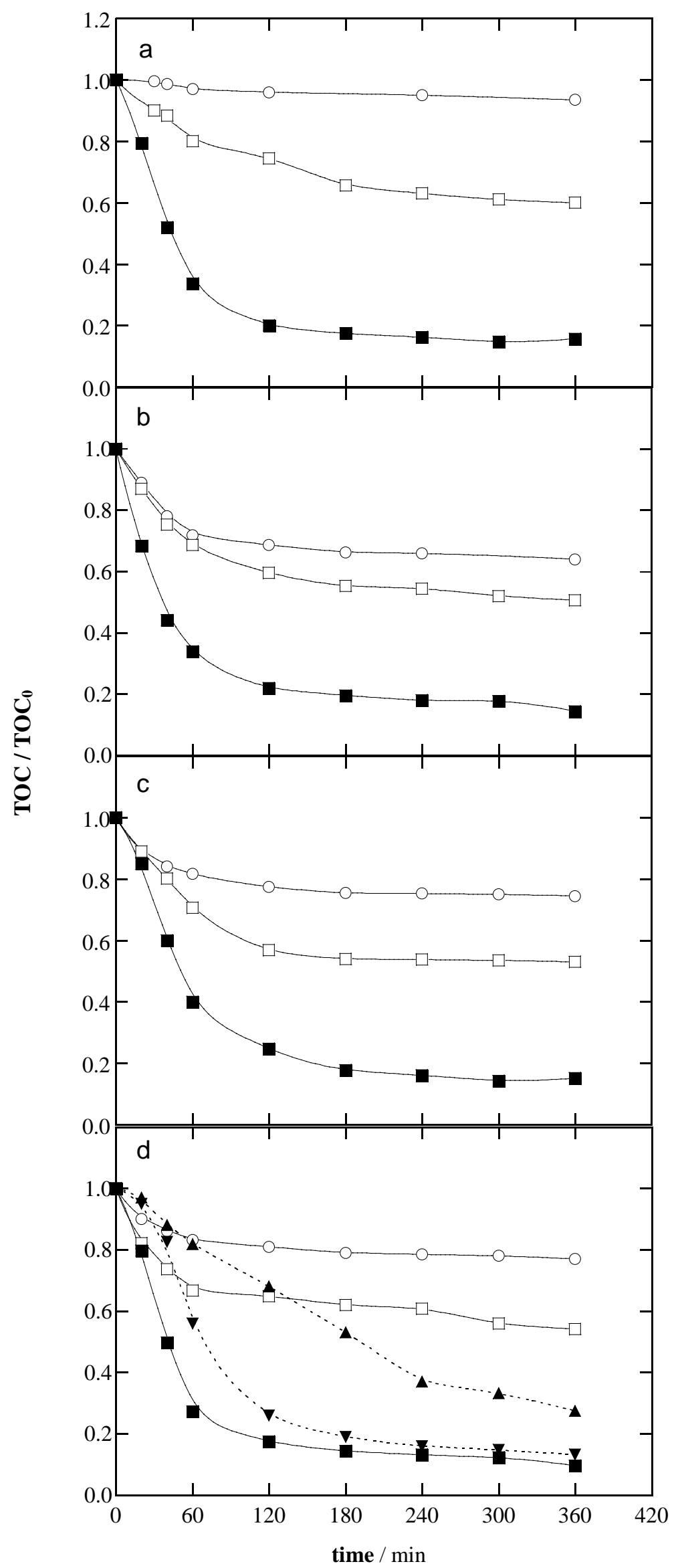

Fig. 2 


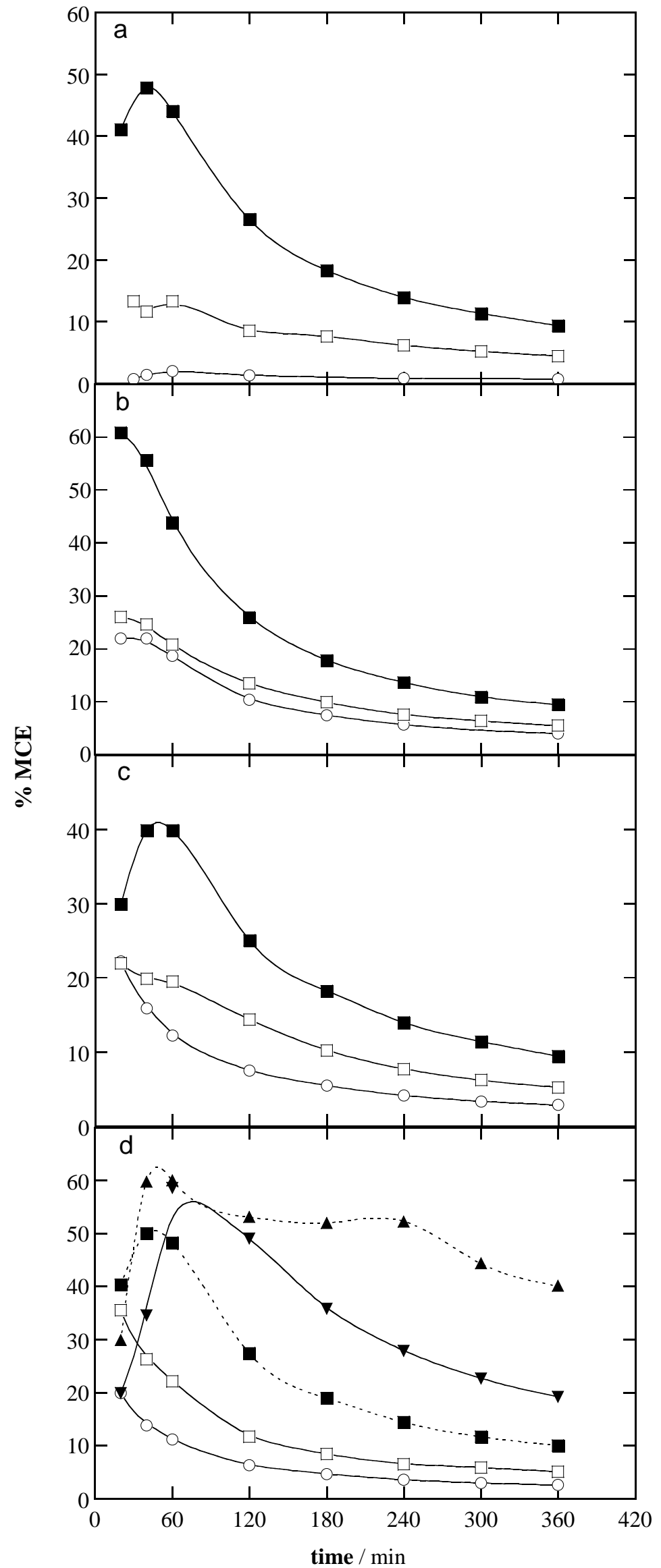

Fig. 3 


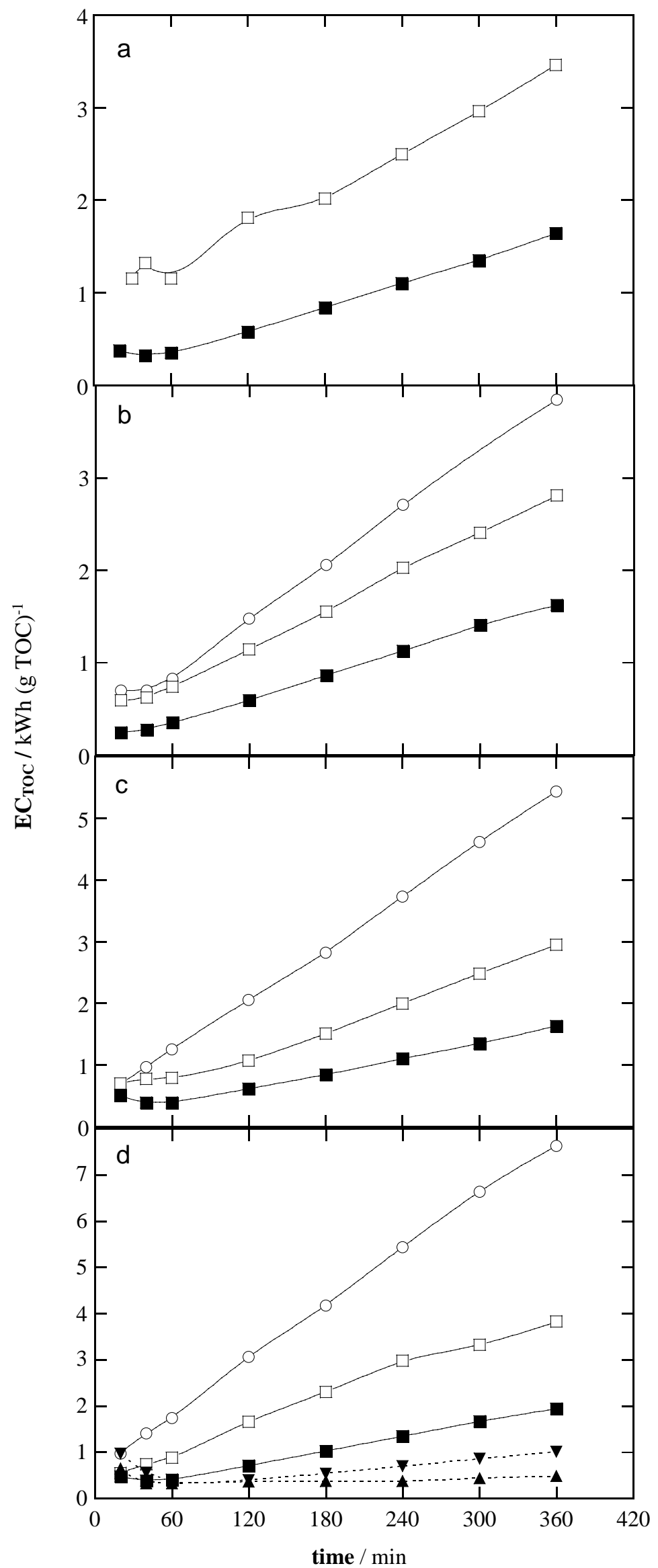

Fig. 4 


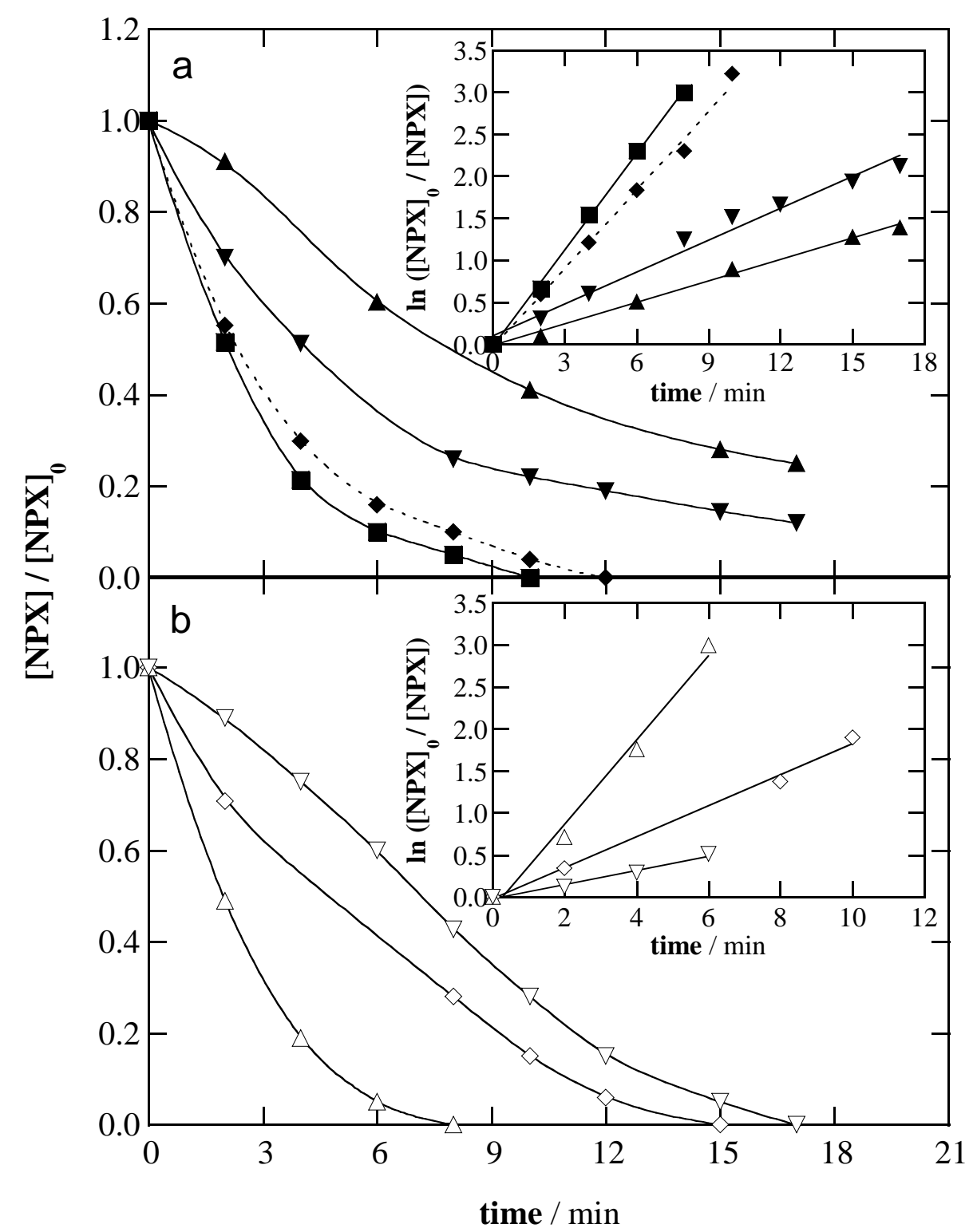

Fig. 5 


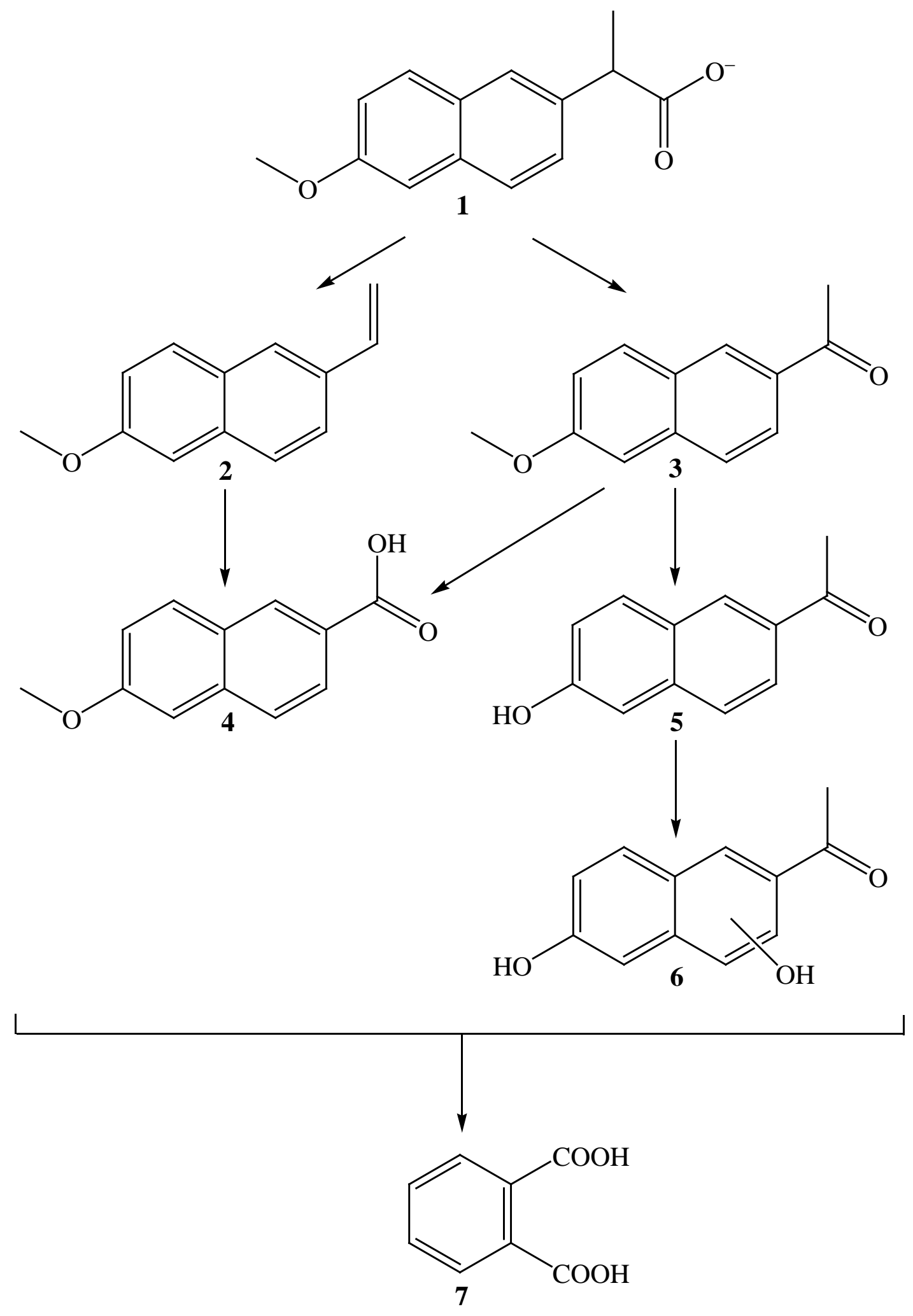

Fig. 6 


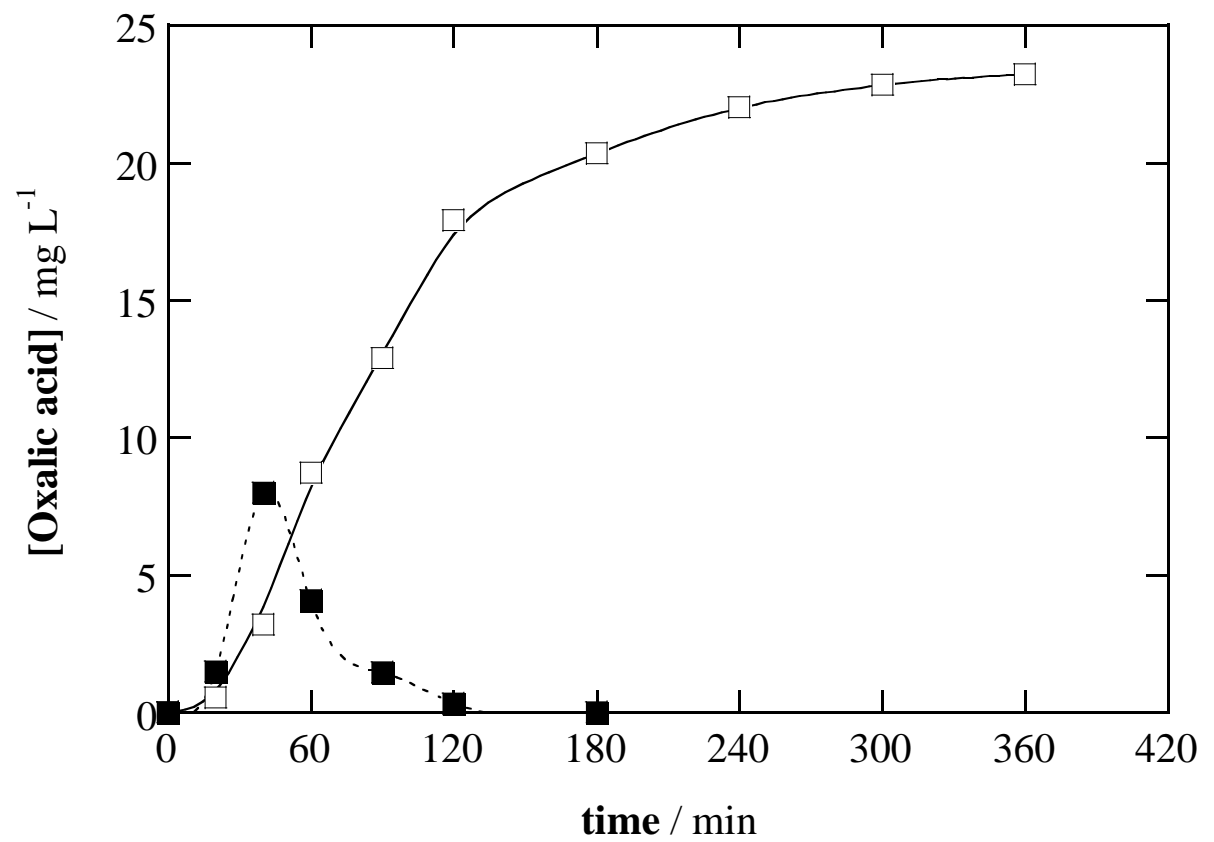

Fig. 7 